\title{
Frequency and Cytokine Phenotype of Blood T Cells from Premature Infants Responding to Staphylococcal Enterotoxin B
}

\author{
ANTHONY R. HAYWARD, MARY COSYNS, AND YINGJIAN ZHANG \\ Department of Pediatrics and Barbara Davis Childhood Diabetes Center, University of Colorado \\ Health Sciences Center, Denver, Colorado 80262.
}

\section{ABSTRACT}

The responder cell frequency $(\mathrm{RCF})$ of premature $(<1900 \mathrm{~g}$ birth weight) infants' blood lymphocytes, which proliferate in cultures stimulated by staphylococcal enterotoxin B, falls from $1: 3400$ to about $1: 8000$ during the first 2 wk of life. Term infants, in contrast, show no fall in RCF. The reduced RCF in the premature infants affected cells that make interferon- $\gamma$ more than cells making IL-4. The reduced RCF was accompanied by a fall in the fraction of $\mathrm{VB3}^{+} \mathrm{T}$ cells that entered cell cycle in stimulated cultures. The RCF of premature infants' $T$ cells was increased in cultures supplemented with irradiated monocytes from adults. Addition of IL-4 (but not IL-2, IL-6, or indometha- cin) increased the RCF and fraction of cells entering cell cycle of the premature infants. The data suggest that postnatal environmental factors limit the ability of premature infants' monocytes to support a $\mathrm{T}$-cell response to staphylococcal enterotoxin $\mathrm{B}$ in vitro and that this limitation is overcome by adding IL-4. (Pediatr Res 37: 455-459, 1995)
RCF, responder cell frequency
SEB, staphylococcal enterotoxin B
IFN, interferon

Premature infants make lower antibody responses to influenza $(1,2)$ and tetanus $(3,4)$ immunization during their first 2 $y$ of life compared with age-matched children born at full term. This finding may be clinically relevant because premature infants have an increased mortality and morbidity from virus infections of the respiratory tract compared with infants born at full term $(5,6)$. Our previous finding that premature infants had lower numbers of influenza antigen-specific $T$ cells than term infants after immunization (2) raises the possibility that impaired $\mathrm{T}$-cell function might limit the antibody response to influenza. The frequency of $\mathrm{T}$ cells in blood that respond to influenza antigen is, however, too low for studies of influenzaspecific $\mathrm{T}$ cells to shed light on the development of T-cell responses in very premature infants. To develop an alternative, antigen-nonspecific, model to quantitate the in vitro responses of blood lymphocytes from human newborns and adults, we determined the frequency and cytokine profiles of blood $\mathrm{T}$ cells responding in vitro to SEB (7). SEB is particularly suited to this purpose as the structure is known (8), together with mechanism by which it binds to MHC molecules (9). Furthermore, the stimulation of $\mathrm{T}$ cells is highly dependent on acces-

Reccived June 20, 1994; accepted December 2, 1994.

Correspondence: Dr. Anthony R. Hayward, B140, University of Colorado School of Medicine, 4200 E. 9th Avenue, Denver, CO 80262.

Supported by a Clinical Research Grant from the March of Dimes and by National Institutes of Health Grants HD13733 and RR 69 from the National Institutes of Health, Division of Research Resources GCRC Program. sory cells or their cytokines $(10,11)$, and the major subset of responding cells can be identified by cell surface expression of the V $\beta 3$ family of T-cell receptors (12). Both IFN- $\gamma$-secreting (TH1-like) and IL-4-secreting (TH2-like) T cells respond to SEB (13).

Our previous studies of premature infants had shown a decreased proliferative response to SEB by blood lymphocytes at 1-2 y of age compared with controls born at term (2). The studies reported here were undertaken to determine whether responses to SEB would be reduced in the neonatal period and, if this were the case, whether there would be differences in the fraction of cells activated and their cytokine profile.

\section{METHODS}

Human subjects. Premature infants born at $<32 \mathrm{wk}$ of gestation weighing $<1900 \mathrm{~g}$ were identified through the Pediatric Clinical Research Center. Blood lymphocytes were recovered from blood samples obtained between 10 and $20 \mathrm{~d}$ of age (mean $14 \mathrm{~d}$ ) for routine biochemical monitoring. These samples had been anticoagulated with preservative-free heparin, and the cells were always processed on the same day as they were drawn. The subjects were studied anonymously, and institutional review board exemption from consent form use was obtained. Blood was also obtained from the placenta of healthy infants born at term. Term infants were defined as born at $>38$ wk of gestation weighing $>2.5 \mathrm{~kg}$. They, and the 
healthy adults whose blood was used as a source of monocytes, were enrolled subject to informed consent.

Lymphocyte cultures. Limiting dilution cultures were performed as described in Hayward et al. (14) except that the replicates of 24 wells contained between 10000 and 300 cells per well and were incubated for $8 \mathrm{~d}$. SEB was obtained from Sigma Chemical Co. (St. Louis, MO) and added at $1 \mu \mathrm{g} / \mathrm{L}$, and cultures were supplemented with $0.001-100 \mathrm{U} / \mathrm{mL}$ recombinant cytokines where shown. Cytokine sources were IL-2: catalog no. 07050 from Amgen, Thousand Oaks, CA, and IL-4: catalog no. 4212-55 and IL-6: catalog no. 4215-00, both from Intergen, Purchase, NY. Indomethacin (Sigma Chemical Co.) was dissolved in DMSO and added to cultures at a final concentration of $0.5 \mu \mathrm{M}$. The wells were pulsed for $6 \mathrm{~h}$ with $0.25 \mu \mathrm{Ci}$ of $\left[{ }^{3} \mathrm{H}\right]$ thymidine, harvested onto glass fiber, and counted on a Betaplate (LKB Wallac, Turku, Finland) reader with dircet data transfer and reduction by $\chi^{2}$ minimalization (15).

To supplement wells with adult adherent cells, adult blood mononuclear cells were obtained as previously described (14). The cells were suspended in RPMI 1640 medium with $1 \%$ human serum at $10^{6}$ cells $/ \mathrm{mL}$, and $10^{5}$ cells were added to the wells of 96-well plates. Nonadherent cells were washed out of the wells after $1 \mathrm{~h}$, and the plate was irradiated with $3000 \mathrm{rad}$ from a ${ }^{60} \mathrm{Co}$ source. Visual examination indicated that these wells contained about 400 adhered cells.

Cultures for cell cycle studies were of whole blood diluted 1:20 with RPMI. Cells bearing T-cell receptor $\beta$-chains of the V $\beta 3$ family were identified by staining with FITC-conjugated antibody (T Cell Diagnostics, Cambridge, MA). These cells were fixed in $80 \%$ methanol, RNase-treated to avoid green staining of RNA, and then stained with propidium iodide. The cell cycle status of the V $\beta 3$ cells was determined by two-color immunofluorescence on an EPICS C (Coulter Electronics, Hialeah, FL) with a logarithmic green scale and linear red scale as previously described (16).

ELISA for cytokines. IL-4 and IFN- $\gamma$ were measured by ELISA as previously described (7). Briefly, Immulon II plates (Dynatech, Chantilly, VA) were coated at $4^{\circ} \mathrm{C}$ overnight with Genzyme (Cambridge, MA) antibodies to human IFN- $\gamma$ (catalog no. 1598-00, diluted 1:300) or IL-4 (catalog no. 1842-01, diluted 1:400) in sodium bicarbonate buffer ( $\mathrm{pH} 8.4)$. The plates were blocked with PBS-gelatin $(1 \mathrm{mg} / \mathrm{mL})$ at $37^{\circ} \mathrm{C}$ for 2 h. Then $20 \mu \mathrm{L}$ of the limiting dilution culture supernatants were added to the wells. The assay was calibrated with recom- binant cytokines, $0.06,0.6$, and $6 \mathrm{U} /$ well for IFN- $\gamma$ and $0.8,4$, and $20 \mathrm{U} /$ well for IL-4. After $2 \mathrm{~h}$, the wells were washed with $0.075 \mathrm{M}$ PBS-Tween four times. The secondary antibodies (rabbit anti-human polyclonal anti-cytokine antibodies) to IFN- $\gamma$ and IL-4 were added at 1:500 diluted in PBS with 1\% FCS and held at $4{ }^{\circ} \mathrm{C}$ overnight. After four washes, a biotinconjugated affinity-purified goat anti-rabbit IgG (Organon Teknika Corp., West Chester, PA) diluted 1:5000 in PBS and $1 \%$ FCS was added, and the plates were incubated at $37^{\circ} \mathrm{C}$ for $2 \mathrm{~h}$. After four washes, alkaline phosphatase-conjugated avidin, diluted 1:5000 in TBS, was added and incubated at $37^{\circ} \mathrm{C}$ for $45 \mathrm{~min}$. The substrate was $p$-nitrophenyl phosphate and glycine buffer (Sigma Chemical Co.) which was prepared and added as directed. The plate was incubated at $37^{\circ} \mathrm{C}$, with the OD read on a Dynatech MR 600 Microplate Reader.

Statistics. RCF results were log-transformed for analysis. Comparisons between groups were by two-tailed Wilcoxon two-sample tests.

\section{RESULTS}

Limiting dilution analyses of SEB RCF. Blood lymphocytes from newborns and 2-wk-old infants, premature and full term, were cultured in U-bottom wells for $8 \mathrm{~d}$ with and without SEB. The RCF calculated by $\chi^{2}$ minimalization (Table 1 ) is significantly lower for newborns and infants compared with adults, in keeping with our previous report. There were, however, no differences in the RCF to SEB by cord blood lymphocytes obtained from premature and term newborns when tested by Spearman rank correlation test. Two weeks after birth, the RCF of lymphocytes from the premature infants is significantly lower than the full-term controls $(p<0.03$, two-tailed test). Inasmuch as there had been no difference in RCF between premature and term newborns, prematurity alone is unlikely to account for the difference in RCF at 2 wk. The response to SEB is highly dependent on monocytes to bind and present the ligand, so we compared the number of blood monocytes in the premature and term infants identified by a differential white cell count, but no difference was found (Table 1).

To determine whether impaired accessory cell function contributed to the reduced RCF to SEB of the premature infants, limiting dilution cultures were supplemented with irradiated adherent cells obtained from unrelated healthy adults. The frequency of cells responding to SEB in these cultures was determined as the increment over cultures with allogeneic

Table 1. Frequency of blood lymphocytes responding to SEB falls in the 2 wh after premature birth

\begin{tabular}{lccccc} 
Subjects & Age & $n$ & Mean RCF $(1: x)$ & 1 SD range $(1: x)$ & Monocytes/ $\mu \mathrm{L}$ \\
\hline Term & Newborns & 12 & 3135 & $2153-4191$ & $1200 \pm 560$ \\
Premature & Newborns & 10 & 3350 & $390-5150$ & ND* \\
Adults & $>20 \mathrm{y}$ & 8 & & & ND \\
& & & 4520 & $2290-6700$ & $960 \pm 470$ \\
Term & $2 \mathrm{wk}$ & 8 & 9400 & $7380-12500$ & $1100 \pm 490$ \\
Premature & $2 \mathrm{wk}$ & 8 & & & \\
\hline
\end{tabular}

RCF results are the frequency of cells responding by proliferation, estimated from limiting dilution cultures. Differences between adults and newborns, either term or premature, are statistically significant $(p<0.05)$, as are differences between the term and premature infants. The monocyte count was calculated from the whitc cell count and the percent monocytes seen in a manual count, \pm 2 SD.

* Not determined. 
Table 2. The RCF to SEB of premature infants' lymphocytes is increased in the presence of irradiated adult adherent cells

\begin{tabular}{lcccc}
\hline \multicolumn{1}{c}{ Subjects } & $\begin{array}{c}\text { Number } \\
\text { tested }\end{array}$ & $\begin{array}{c}\text { Added } \\
\text { adhered cells }\end{array}$ & $\begin{array}{c}\text { Mean RCF } \\
(1: x)\end{array}$ & $\begin{array}{c}\text { 1 SD Range } \\
(1: x)\end{array}$ \\
\hline Prematures & 3 & None & 8800 & $6220-9460$ \\
Prematures & 3 & Adult & 3950 & $2250-4680$ \\
Newborns & 4 & None & 3400 & $2160-4480$ \\
Newborns & 4 & Adult & 3130 & $2400-4100$ \\
\hline
\end{tabular}

Premature infant cells were from subjects with a mean age of $14 \mathrm{~d}$. Newborns were term infants. The frequency of cells responding to SEB was calculated as the increment in RCF over wells containing allogeneic monocytes alone.

monocytes but without SEB. The results (Table 2) indicate that the RCF of the premature infants was increased to levels found in term controls in these cultures. The response to SEB by term infants' cells was not increased by the presence of adult monocytes.

The ability of adult monocytes to increase the RCF to SEB argued against in vitro suppression of the $\mathrm{T}$-cell response by soluble mediators such as prostaglandin $\mathrm{E}_{2}$. To exclude a role for prostaglandin $E_{2}$ suppression, cultures were supplemented with $0.5 \mu \mathrm{M}$ indomethacin, a cyclooxygenase inhibitor. No increase in the response of premature infants' $\mathrm{T}$ cells to SEB was found in these cultures (data not shown).

Cytokine phenotype of cells responding to SEB. To determine whether the reduced response of the premature infants when tested at 2 wk of age affected mainly TH1- or TH2-like cells, we measured IFN- $\gamma$ and IL-4 in the supernatants of the limiting dilution culture wells. Responder wells were defined as those with cytokine levels above the (mean $\pm 2 \mathrm{SD}$ ) for the unstimulated controls. Applying the $\chi^{2}$ minimalization procedure to these data gives an estimate of the precursor frequency of IFN- $\gamma$ - and IL-4-making cells. When applied to cord blood cells stimulated for $5 \mathrm{~d}$ with $\mathrm{SEB}$, this method shows a mean of $1: 98000$ cells as positive for IFN- $\gamma$ and $<1: 10^{5}$ as positive for IL-4. The results for the 14-d-old infants (Table 3) show a statistically significant reduction in IFN- $\gamma$-making cells among those born prematurely. Fewer cells made IL-4, and although there was a trend toward lower frequencies of responders among the premature infants, it did not reach statistical significance.

Table 3. Frequency of $I F N-\gamma$ and $I L-4$ making cells in SEB-stimulated cultures of infants 14 days after premature or term birth

\begin{tabular}{clcc}
\hline & & Mean RCF & 1 SD rangc \\
Subjects $(n)$ & End point & $(1: \mathrm{x})$ & $(1: \mathrm{x})$ \\
\hline Term infants $(8)$ & Proliferation & 4,300 & $2260-8600$ \\
& IFN- $\gamma$ & $53,360 *$ & $38110-74700$ \\
& IL-4 & 60,840 & $43460-85180$ \\
& & & \\
Premature infants (6) & Prolifcration & 8,890 & $4420-17000$ \\
& IFN- $\gamma$ & $84,850^{*}$ & $60610-118790$ \\
& IL-4 & 71,870 & $51340-100620$ \\
\hline
\end{tabular}

Wells were defined as positive for IFN- $\gamma$ or IL- 4 when their level was $>$ mean $+2 \mathrm{SD}$ for the parallel unstimulated controls.

* The frequency of IFN- $\gamma$ making cells in premature and term infants differs significantly $(p<0.05)$.
Cell cycle entry in SEB stimulated cultures. The reduced RCF of the premature infants might have resulted from reduced activation of $\mathrm{T}$ cells in the cultures. To confirm this possibility, we measured the fraction of $V \beta 3$ cells that entered cell cycle after SEB stimulation. The results (Fig. 1) show a daily increment in the percentage of V $\beta 3$ cells that have moved out of $G_{0}$ into cell cycle through the first $4 \mathrm{~d}$ of culture. The percentage of $\mathrm{V} \beta 3$ cells remained between 4 and $8 \%$ for the first $3 \mathrm{~d}$ of culture but from the fourth day of culture onward increased, presumably due to the replication of this subset. The fraction of $\mathrm{V} \beta 3$ cells in cycle after $3 \mathrm{~d}$ of culture is similar in term newborns $(32.1 \%)$ and premature infants $(30.3 \%)$ when measured in the first days of life. However, the percentage of the premature infants' V $\beta 3$ cells that entered cell cycle in SEBstimulated cultures fell to a mean of $19 \%$ (range 13-25\%) 14 $\mathrm{d}$ after birth. This was significantly less than the $30.3 \%$ of $\mathrm{V} \beta 3$ cells that were in cycle from infants aged $14 \mathrm{~d}$ who had bcen born at term (Fig. 2). Because the activation of naive $T$ cells by SEB requires a range of second signals, including IL-2, IL-4, and IL-6, we measured cell cycle entry in the presence of added cytokines. The results (Fig. 2) indicate that $50 \mathrm{U} / \mathrm{mL}$ of IL-4 was able to increase the percentage of the premature infants' V $\beta 3$ cells entering cell cycle to control levels. Neither IL-2 nor IL-6 had an effect at concentrations up to $100 \mathrm{U} / \mathrm{mL}$ (not shown).

The effect of IL-4, together with IL-2 and IL-6, was also tested in limiting dilution cultures with SEB. The results show a statistically significant increase in response by premature infants' T cells with IL-4 (Table 4) but no influence of IL-2 or IL-6 at levels up to $100 \mathrm{U} / \mathrm{mL}$. Addition of IFN- $\gamma$ at $100 \mathrm{U} / \mathrm{mL}$ also had no effect (not shown). The RCF of the term infants appears to fall in the presence of IL-2 concentrations $>10$ $\mathrm{U} / \mathrm{mL}$. This is an artifact caused by an increase in thymidine uptake in the unstimulated control wells, from which the mean $\pm 3 \mathrm{SD}$ cutoff point for responder wells is calculated.

\section{DISCUSSION}

Evidence for impaired cell-mediated immune responses after premature birth is indirect and at best inconclusive when the stressful environment of neonatal intensive care is taken into account. The number of studies of T-cell function of premature infants has been limited by the very small volumes of blood

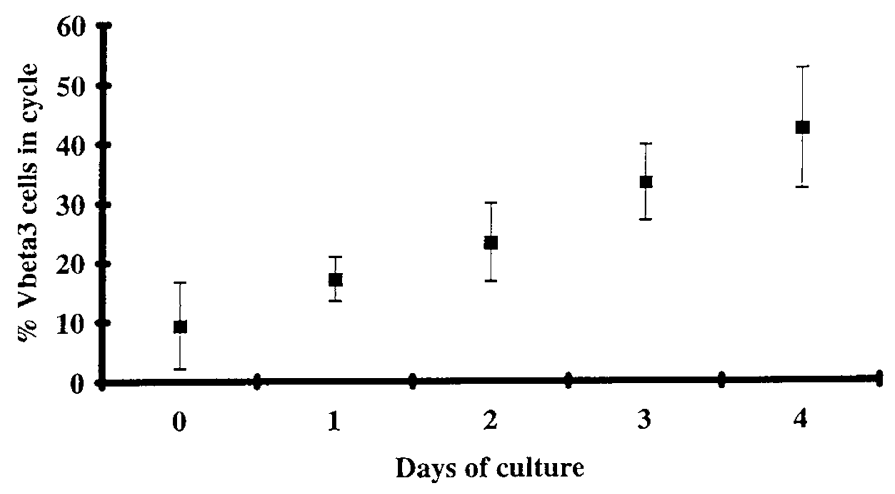

Figure 1. Percentage of newborns' $V \beta 3^{+\cdot} \mathrm{T}$ cells in cell cycle on different days after stimulation by SEB. Ranges shown are \pm 1 SD. 


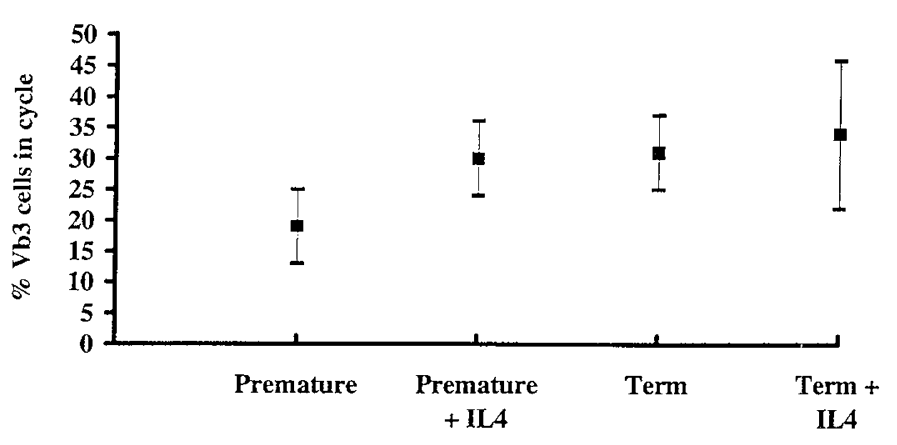

Figure 2. Cell cycle entry by premature infant $\mathrm{V} \beta 3 \mathrm{~T}$ cells is increased when $50 \mathrm{U} / \mathrm{mol} \mathrm{IL-4}$ is added to cultures. The difference is statistically significant ( $p<0.05$ by Wilcoxon two-sample statistic, $n=8$ for premature infants and control groups, respectively). Ranges shown are \pm 1 SD.

Table 4. Effects of added cytokines on RCF to SEB of lymphocytes from infants $14 \mathrm{~d}$ after premature or full-term birth

\begin{tabular}{llccc}
\hline & \multicolumn{2}{c}{ Prctcrm infants } & \multicolumn{2}{c}{ Tcrm infants } \\
\hline Stimulus & RCF 1:x & \multicolumn{1}{c}{ Range } & RCF 1:x & Range \\
SEB & 8700 & $7620-9850$ & 3400 & $2430-3870$ \\
SEB + IL-2 & 7900 & $6800-10200$ & 6620 & $2400-4620$ \\
SEB + IL-4 & $4400^{*}$ & $4020-5530$ & 3300 & $2780-3770$ \\
SEB + IL-6 & 8100 & $7000-10100$ & 3500 & $2870-4450$ \\
\hline
\end{tabular}

Results are from five premature and five term infants. Data shown were obtained with $50 \mathrm{U} / \mathrm{mL}$ cytokines.

* The preterm response to SEB in the presence of IL-4 is significantly greater than the control without cytokine or in the presence of IL-2 or IL-6 ( $p$ $<0.05)$.

available, and the approaches used have been relatively nonspecific. Phenotyping studies indicate that premature infants have as many $T$ cells as full-term controls $(17,18)$. Proliferation of premature infants' $\mathrm{T}$ cells obtained on the day of birth and stimulated by phytohemagglutinin were similar to adults in some studies $(19,20)$ and low in others $(21)$, but possible contributions of impaired accessory cell function or deficiency of a subset of $T$ cells have not been examined. The wider use of immunization to prevent infectious diseases after premature birth has refocused attention on immunity development (or impairment) in ex-premature infants. Particularly important in this context is the duration of any impairment in T-cell response. Bussel et al. (22), for example, found a modest impairment of response to phytohemagglutinin in premature infants which was greatest at birth and persisted for at least the first 2 mo of life.

Our own studies point to a reduced frequency of influenzaspecific $\mathrm{T}$ cells (accompanied by lower antibody responses) to influenza in a population of premature infants aged 1-2 y who were compared with age-matched healthy controls born at term (2). This result suggested that premature birth could diminish the antibody response to immunization for as long as 24 mo after birth. Analysis of T-cell development in the first weeks of life requires ligands, such as SEB, which stimulate a large number of cells. By combining SEB stimulation with quantitative end points, such as limiting dilution cultures, and cell cycle analysis, we have been able to explore, using very small volumes of blood, the activation of cells defined by their $\mathrm{V} \beta$ expression. A weakness of SEB as a model activating agent is that no processing by the antigen-presenting cells is required, that binding to class II MHC occurs outside the antigenbinding cleft, and binding to the T-cell receptor is through the $\beta$-chain rather than the $\alpha \beta$ combination (9). Nevertheless, live antigen-presenting cells are required to support a proliferative response, because the response to SEB is accessory factor dependent (11). Newborns' monocytes have mature antigenpresenting cell function (23), and the reduced response of newborn T cells to SEB is at least in part associated with their CD45RA phenotype (24) and the intrinsically lower response of this subset to SEB (25).

The frequency of term infants' $\mathrm{V} \beta 3^{+} \mathrm{T}$ cells that entered cell cycle or proliferated in SEB-stimulated cultures remained roughly constant during the first weeks of life. Response by the premature infants' $V \beta 3^{+}$cells fell significantly during the same time period, whether measured as the frequency of cells entering cell cycle or the frequency proliferating in limiting dilution. The frequency of term infants' cells making IFN- $\gamma$ at $2 \mathrm{wk}$ of age is higher than at birth (1:53 000, compared with the $1: 98000$ we found for newborns). Because $<1: 10^{5}$ newborns' mononuclear cells made IL-4 in cultures stimulated by SEB, the frequency of wells positive for this cytokine almost doubled in the first 2 wk of life. The number of cells positive for IFN- $\gamma$ and IL-4 detected in the limiting dilution cultures reported here is less than that we previously reported as positive in an Elispot assay (7). It is likely that this difference results from proliferation by cells responding to SEB in the Elispot assay, as shown by our measurements of $\mathrm{V}_{3} 3^{+}$cells in SEB-stimulated cultures in the present study (Fig. 1). In limiting dilution cultures the estimate of frequency of precursors of cytokine-making cells is less open to increase as a result of proliferation.

It is likely that reduced availability of accessory cells or their factors contributed to the fall in SEB response of the premature infants in the first 2 wk of life, as their cells responded as well as term infants' cells in the presence of adult monocytes. The reconstitution that followed the addition of MHC-mismatched adult monocytes is open to multiple interpretations, including the production of cytokines by premature infants' $\mathrm{T}$ cells responding to the unrelated histocompatibility antigens of the adults' monocytes. Although some alloantigen stimulation undoubtedly occurred, it did not obscure the response to SEB. The small proportion of allogeneic monocytes (about 400 cells) that was cultured with $10^{5}$ responder MNC may have contributed to our continuing ability to detect a response to SEB. Together with the increase in premature infants' $\mathrm{V} \beta 3^{+}$that entered cell cycle in the presence of SEB, the result argues against an active suppression by the newborns' monocytes of T-cell responses to SEB. Nonspecific suppression by the premature infants' monocytes, such as the autocrine suppression of monocyte cytokine production by prostaglandin $E_{2}(26)$, is also unlikely, because the reconstitution provided by adult monocytes occurred in the continuing presence of the newborns' monocytes. This interpretation is supported by our failure to increase the response of premature infants' $T$ cells to SEB by adding indomethacin to the cultures.

Of the cytokines that were tested, only IL-4 was able to restore the premature infants' response to the levels of the term 
controls, whether the end point was the fraction of $V \beta 3$ cells entering cell cycle or the RCF. The mechanism by which IL-4 boosted the response of premature infants' MNC to SEB remains to be established. IL-4 is a multifunctional cytokine that modulates the cytokine profile of T-cell responses, amplifying the IL-4 component and tending to diminish the IFN- $\gamma$ component (27). IL-4 can act directly on $\mathrm{T}$ cells, including naive $\mathrm{T}$ cells $(28)$, to maintain their proliferation in culture. IL-4 also acts on monocytes to modulate their expression of integrins (29) and to increase their expression of cell surface HLA-DR and DP molecules (30). Any of these effects could contribute to an increase in the frequency of $\mathrm{T}$ cells responding to SEB. The principal conclusion of the reconstitution experiments, whether by adult monocytes or IL-4, is that the premature infants' $V \beta 3$ cells retained the potential for response.

In summary, our results provide evidence for an acquired defect in premature infants' blood monocytes that limits their ability to present a T-cell ligand, SEB, to ${\mathrm{V} B 3^{+}}^{+} \mathrm{T}$ cells. The nature of the defect, and its duration, remain to be established. Prospective studies will be required to determine whether impairment of T-cell responses to SEB in the first weeks of life correlates with any alteration in susceptibility to infection or ability to respond to immunization.

Acknowledgments. The authors thank Donna Rodden, the CRC nurses, and the staff of the Child Health Clinic for identifying and obtaining blood samples from premature infants.

\section{REFERENCES}

1. Groothuis JR, Levin MJ, Lehr MV, Weston JA, Hayward AR 1992 Impaired immune response to split product influenza vaccine in high-risk young children. Vaccine $10: 221-225$

2. Li J, Groothuis JR, Lehr MV, Hayward AR 1993 Reduced anti-influenza antibody and $T$ cell proliferative response to staph enterotoxin $B$ in prematurely born infants. Immunol Infect Dis 3:113-117

3. Bcrnbaum JC, Daft A, Anolik R, Samuelson J, Barkin R, Douglas S, Polin R 1985 Response of preterm infants to diphtheria tetanus pertussis immunizations. J Pediatr 107:184-188

4. Bernbaum J, Daft A, Samuelson J, Polin RA 1989 Half dose immunization for diphtheria, tetanus, pertussis: response of preterm infants. Pediatrics 83:471-476

5. Henderson FW, Collier AM, Clyde WA, Denny FW 1979 Respiratory syncytial virus infections, reinfections and immunity. A prospective study in young children. N Engl J Med 300:530-534

6. Liou Y, Barbour SD, Bell LM, Plotkin SA 1987 Children hospitalized with influenza B infection. Pediatr Infect Dis J 6:541-543

7. Hayward AR, Cosyns M 1994 Proliferative and cytokine responses by human newborn T cells stimulated with staphylococcal enterotoxin B. Pediatr Res 35:293298
8. Swaminathan S, Furey W, Pletcher J, Sax M 1992 Crystal structure of staphylococcal enterotoxin B, a superantigen. Nature 359:801-806

9. Jardetsky TS, Brown JH, Gorga JC, Stern LJ, Urban RG, Chi Y, Stauffacher C, Strominger JL, Wiley DC 1994 Threc-dimensional structure of a human class II histocompatibility molecule complexed with superantigen. Nature 368:711-718

10. Fraser JD 1989 High affinity binding of staphylococcal enterotoxins A and B to HLA DR. Nature 339:221-223

11. Carlsson R, Fischer H, Sjogren HO 1988 Binding of staphylococcal enterotoxin A to accessory cells is a requirement for its ability to activate human $\mathrm{T}$ cclls. J Immunol $140: 2480-2488$

12. Irwin MJ, Hudson KR, Fraser JD, Gascoigne NR 1992 Enterotoxin residues determining T-cell receptor $\mathrm{V}$ beta binding spccificity. Naturc 359:841-843

13. O'Hehir RE, Yssel H, Verma S, de Vries JE, Spits H, Lamb JR 1991 Clonal analysis of differential lymphokine production in peptide and superantigen induced $\mathrm{T}$ cell anergy. Int Immunol 3:819-826

14. Hayward AR, Zerbe GO, Levin MJ 1994 Clinical application of responder cell frequency estimates. J Immunol Methods 170:27-36

15. Wilson RA 1981 Quantitation of functional $\mathrm{T}$ cells by limiting dilution. In: Coligan JE, Kruisbeek AM, Margulies DH, Shevach EM, Strober W (eds) Current Protocols in Immunology. John Wiley \& Sons, New York, pp 3.15.1-3.15.12

16. Carotenuto P, Pontesilli O, Cambier JC, Hayward AR 1986 Desferoxamine blocks IL-2 reccptor expression on human T lymphocytes. J Immunol 136:2342-2347

17. Thomas RM, Linch DC 1983 Identification of lymphocyte subsets in the newborn using a variety of monoclonal antibodies. Arch Dis Child 58:34-38

18. Ballow M, Cates KL, Rowe JC, Goetz C, Pantschenko AG 1987 Peripheral blood $\mathrm{T}$-cell subpopulations in the very low birth weight (less than $1-500 \mathrm{~g}$ ) infant. Am J Hematol 24:85-92

19. Haneberg B, Bertnes E, Ulstein M 1980 Mitogen induced multiplication of lymphocytes from newborn infants. Eur J Pediatr 134:23-26

20. Pittard WB, Miller K, Sorensen RV 1984 Normal lymphocyte responses to mitogens in term and premature neonates following normal and abnormal intrauterine growth. Clin Immunol Immunopathol 30:178-187

21. Leino A, Ruuskanen O, Kero P, Eskola J, Toivanen P 1981 Depressed phytohemagglutinin and concanavalin $\mathrm{A}$ responses in premature infants. Clin Immunol Immunopathol 19:260-267

22. Bussel JB, Cunningham-Rundles S, LaGamma EF, Shellabarger M 1988 Analysis of lymphocytc proliferative response subpopulations in very low birth weight infants and during the first 8 wk of life. Pediatr Res 23:457-462

23. Hoffman AA, Hayward AR, Kurnick JT, DeFreitas E, McGregor J, Harbeck RJ 1981 Presentation of antigen by human newborn monocytes to maternal tetanus totoid specific T cell blasts. J Clin Immunol 1:217-222

24. Hayward AR, Lec J, Beverley PCL 1989 Ontogeny of expression of UCHL1 antigen on TcR1 (CD 4:8) and TcR $\delta$ T cells. Eur J Immunol 19:771-773

25. Sanders ME, Makgoba MW, Junc CH, Young HA, Shaw S 1989 Enhanced responsiveness of human memory $T$ cells to $\mathrm{CD} 2$ and $\mathrm{CD} 3$ receptor mediated activation. Eur J Immunol 19:803-807

26. Kunkel SL, Spengler M, May MA, Spengler R, Larrick J, Remick D 1988 Prostaglandin $\mathrm{E}_{2}$ regulated macrophage derived tumor necrosis factor gene expression. J Biol Chem 263:5380-5384

27. Paul WE, Seder RA 1994 Lymphocyte responses and cytokines. Cell 76:241-251

28. Wu CY, Demeure CE, Gately M, Podlaski F, Ysscl H, Kiniwa M, Delespesse G 1994 In vitro maturation of human neonatal $\mathrm{CD} 4 \mathrm{~T}$ lymphocytes. I. Induction of IL-4 producing cells after long-term culture in the presence of IL-4 plus either IL-2 or IL-12. J Immunol 152:1141-1153

29. Bogdan C, Nathan C 1993 Modulation of macrophage function by transforming growth factor $\beta$, interleukin 4 and interlcukin 10. Ann NY Acad Sci 685:713-739

30. Gerrard TL, Dyer DR, Mostowski HS 1990 IL4 and granulocyte macrophage CSF sclectively increase HLA-DR and HLA-DP antigens but not HLA-DQ antigens on human monocytes. J Immunol 114:4670-4674 